Kumawula, Vol. 3, No.3, Desember 2020, Hal 548 - 560 DOI: https://doi.org/10.24198/kumawula.v3i3.32013

ISSN 2620-844X (online)

Tersedia online di http://jurnal.unpad.ac.id/kumawula/index

\title{
PENERAPAN MODEL PENGELOLAAN SAMPAH "POJOK KANGPISMAN"
}

\author{
Bintarsih Sekarninngrum $^{\mathbf{1}^{*}}$, Yogi Suprayogi $\mathrm{S}^{2}$, Desi Yunita ${ }^{3}$ \\ ${ }^{1}$ Fakultas Ilmu Sosial dan Ilmu Politik, Universitas Padjadjaran \\ ${ }^{2}$ Fakultas Ilmu Sosial dan Ilmu Politik, Universitas Padjadjaran \\ ${ }^{3}$ Fakultas Ilmu Sosial dan Ilmu Politik, Universitas Padjadjaran \\ *Korespondensi : bintarsih.sekarningrum@unpad.ac.id
}

\begin{abstract}
The root of the waste management problem is that there are weaknesses in various aspects such as budget constraints, inadequate management systems, weak law enforcement, lack of community participation, limited land and waste management facilities, and low levels of application of environmentally friendly technology. Therefore, it is necessary to change behavior and culture in society to reduce waste and encourage the principles of waste management through reduce-reuse-recycle (3R) or in Bandung it is known as the "Kangpisman Movement" (reduce, separate, and utilize). "Kangpisman Corner" is an alternative model in community-based waste management at the Rukun Warga (neighbourhood association) level whose management requires community participation in processing waste through the "Kangpisman Movement". This activity uses techniques such as distributing questionnaires to households in the study area related to the implementation of the Kangpisman movement at the household level; Focus group discussions to determine the effectiveness of the Kangpisman Corner model at all levels (community and household) and create videos to describe waste management models "Kangpisman Corner". The results of this activity show that waste management with the Kangpisman Corner model has been implemented at all levels (community and household) and the community has participated in waste management based on their awareness. However, the participation of stakeholder and social institutions at the Rukun Warga (neighbourhood association) level is needed, so that this movement is maintained. In conclusion, the Kangpisman Corner model is considered effective for processing waste because it is in a smaller scope, the community will participate because they are involved in the process.
\end{abstract}

Keywords : Community based waste management, Kangpisman movements, Kangpisman Corner, waste free zone, waste management model

\begin{abstract}
ABSTRAK
Akar permasalahan pengelolaan sampah yaitu terdapat kelemahan pada berbagai aspek seperti keterbatasan anggaran, sistem manajemen yang belum optimal, lemahnya penegakan hukum, kurangnya partisipasi masyarakat, keterbatasan lahan dan fasilitas pengelolaan sampah, serta rendahnya tingkat penerapan teknologi ramah lingkungan. Terkait dengan permasalahan tersebut, diperlukan perubahan perilaku dan budaya untuk mengurangi sampah dan mendorong masyarakat menerapkan prinsip pengelolaan sampah melalui 3R (Reduce, Reuse dan Recycle) atau dikenal dengan "Gerakan Kangpisman" (kurangi, pisahkan dan manfaatkan). "Pojok Kangpisman” adalah salah satu model alternatif dalam pengelolaan sampah berbasis masyarakat di tingkat Rukun Warga yang pengelolaannya menuntut adanya partisipasi masyarakat dalam mengolah sampah melalui "Gerakan Kangpisman”. Kegiatan ini dilaksanakan melalui beberapa teknik yaitu menyebarkan angket terhadap rumah tangga yang ada di wilayah kajian terkait dengan penerapan gerakan Kangpisman di tingkat rumah tangga; melakukan focus group discussion untuk mengetahui efektivitas model pengelolaan sampah Pojok Kangpisman baik di tingkat komunitas maupun di tingkat rumah tangga dan membuat video untuk mendeskripsikan pengelolaan sampah model "Pojok Kangpisman". Hasil kegiatan menunjukkan bahwa model pengelolaan sampah Pojok Kangpisman telah diterapkan baik di tingkat komunitas maupun rumah tangga serta masyarakat telah berpartisipasi dalam pengolahan sampah atas dasar kesadarannya. Namun peran serta stakeholder dan kelembagaan sosial yang ada di tingkat Rukun Warga sangat diperlukan, agar gerakan Kangpisman tetap berjalan dan terjaga
\end{abstract}


kesinambungannya. Simpulan, model pengelolaan sampah Pojok Kangpisman dianggap efektif untuk melakukan pengolahan sampah karena berada dalam lingkup yang lebih kecil yaitu di tingkat Rukun Warga dan masyarakat akan berpartisipasi karena terlibat dalam prosesnya.

Kata kunci : Gerakan Kangpisman, Kawasan Bebas Sampah, model pengelolaan sampah, pengelolaan sampah berbasis masyarakat, Pojok Kangpisman

\section{PENDAHULUAN}

Sampai saat ini sampah masih menjadi persoalan bagi masyarakat di Indonesia. Hal ini disebabkan karena meningkatnya konsumsi masyarakat terhadap produk penunjang aktivitas sehari-hari seiring dengan bertambahnya jumlah penduduk (Istiningdias, Azijah, \& Argenti, 2019). Kementerian Lingkungan Hidup dan Kehutanan (2020) menyatakan bahwa permasalahan sampah sudah menjadi permasalahan serius. Setiap tahun terjadi peningkatan volume sampah, yaitu sebesar 1 juta ton dengan sumber sampah terbanyak berasal dari rumah tangga (62\%) dan jenis sampah terbanyak adalah sampah organik diikuti sampah plastik dan kertas (Kementerian Lingkungan Hidup dan Kehutanan, 2020).

$$
\text { Beberapa faktor penyebab }
$$

permasalahan sampah yaitu kondisi TPA di wilayah Indonesia telah kritis dan tidak dapat lagi menampung sampah di TPA. Kondisi tersebut semakin diperparah dengan pengelolaan sampah yang bertumpu pada model pengelolaan sampah tradisional yaitu kumpul-angkut-buang yang bertumpu di TPA. Selain itu, kesadaran masyarakat terhadap pengelolaan sampah masih rendah. Berdasarkan laporan Biro pusat Statistik (2018) tentang Indeks Perilaku Ketidakpedulian Lingkungan Hidup, dinyatakan bahwa sebanyak 72 persen orang Indonesia tidak peduli terhadap sampah. Faktor lainnya adalah anggaran daerah terhadap pengelolaan sampah juga masih kurang. Pernyataan yang sama dikemukakan oleh Wahyono (2018) bahwa akar masalah dari buruknya pengelolaan sampah adalah karena kelemahan pada berbagai aspek seperti keterbatasan anggaran, sistem manajemen yang belum optimal, lemahnya penegakan hukum, lemahnya peran serta masyarakat, keterbatasan lahan untuk fasilitas pengelolaan sampah, rendahnya tingkat penerapan teknologi ramah lingkungan, dan sebagainya.

Terkait dengan permasalahan tersebut, tentunya diperlukan perubahan perilaku dan budaya secara untuk mengurangi sampah dan mendorong masyarakat untuk menerapkan prinsip pengelolaan sampah melalui 3R: Reduce, Reuse dan Recycle, serta membantu pemerintah dalam penanganan sampah di masyarakat. Upaya ini dapat diwujudkan dengan adanya kerjasama dalam pengelolaan sampah antara pemerintah daerah, organisasi, pihak swasta dan masyarakat dalam rangka mencapai target pengurangan sampah sebesar 30 persen dan penanganan sampah 70 persen pada tahun 2025 (Kementerian Lingkungan Hidup dan Kehutanan, 2020).

Salah satu upaya yang dilakukan Kota Bandung untuk mengatasi masalah sampah, yaitu mengembangkan sebuah model pengelolaan sampah yang dititikberatkan pada pelibatan warga dengan meluncurkan sebuah program yang dinamakan "Gerakan Kangpisman” (Kurangi, Pisahkan, Manfaatkan Sampah) yang merupakan upaya untuk mengurangi, memisahkan dan memanfaatkan sampah yang diluncurkan pada tahun 2018 (Sekarningrum, Sugandi, \& Yunita, 2020). Pada awal pengembangan program, terdapat delapan kelurahan yang menjadi model percontohan dalam penerapan Kawasan Bebas Sampah (KBS). Delapan kelurahan tersebut yaitu kelurahan Sukamiskin, Sukayulu, Gempolsari, Cihaurgeulis, Mengger, Neglasari, Babakansari, dan Kebon Pisang (Humas Bandung, 2018). Kelurahan tersebut menjadi percontohan KBS, karena diindikasikan telah ada perkembangan upaya komunitas masyarakat dalam melakukan pengelolaan sampah secara mandiri. Dari delapan kelurahan percontohan tersebut diharapkan terjadi perubahan perilaku dalam pengelolaan sampah di masyarakat, sehingga dapat mendorong perubahan budaya masyarakat. Perubahan 
budaya dan perilaku masyarakat akan berdampak terhadap masyarakat dan lingkungan.

Pemerintah Kecamatan Cinambo Kota Bandung yang merupakan wilayah kegiatan Pengabdian kepada Masyarakat (PPM) turut mendukung program pemerintah Kota Bandung dalam menerapkan gerakan Kangpisman secara mandiri. Pada awal gerakannya (tahun 2018), Kecamatan Cinambo mengawali dengan menggagas setiap kelurahan untuk menerapkan wilayah Kawasan Bebas Sampah. Namun, dalam perkembangannya, gerakan Kangpisman yang dilaksanakan masih belum masif, sehingga kegiatan sosialisasi dan edukasi gerakan Kangpisman menjadi dasar bagi pelaksanaan kegiatan Pengabdian pada Masyarakat di tahun 2019. Dari kegiatan tersebut, selanjutnya mengembangkan gagasan bersama warga masyarakat untuk menerapkan model pengelolaan sampah "Pojok Kangpisman” di tingkat Rukun Warga, sebagai salah satu bentuk dukungan masyarakat dalam pelaksanaan gerakan Kangpisman di lingkungan Kecamatan Cinambo.

Model pengelolaan sampah "Pojok Kangpisman” merupakan salah satu alternatif dalam pengelolaan sampah berbasis masyarakat khususnya di tingkat Rukun Warga. Model ini perlu diterapkan dan dilakukan evaluasi terhadap pelaksanaannya, agar model yang diterapkan dapat mengubah perilaku masyarakat dalam memperlakukan dan mengolah sampah untuk mewujudkan Kawasan Bebas Sampah melalui gerakan Kangpisman.

Dalam penerapannya, model pengelolaan sampah "Pojok Kangpisman" membutuhkan keterlibatan anggota masyarakat dan kelembagaan yang ada, sehingga sampah yang ada di wilayah tersebut dapat dikurangi, dipisahkan, dan dimanfaatkan kembali agar lingkungan yang bersih dan sehat dapat diwujudkan. Penerapan model Pojok Kangpisman di setiap rukun warga perlu disesuaikan dengan kondisi potensi yang dimiliki oleh masing-masing wilayah, baik dari potensi kelurahan, kelembagaan sosial (PKK, Karang Taruna, LPM, Majelis Taklim), lingkungan Rukun Warga (RW) maupun pihak swasta. Kegiatan ini dilaksanakan, karena belum adanya model pengelolaan sampah berbasis masyarakat di tingkat rukun warga yang mampu menggerakkan masyarakat untuk melakukan gerakan Kangpisman atas dasar kesadaran dan partisipasinya. Selain itu, stakeholder dan kelembagaan sosial yang ada di tingkat rukun warga belum dilibatkan secara maksimal dalam menyebarluaskan gerakan Kangpisman terhadap semua rumah tangga yang ada di wilayahnya.

Atas dasar pertimbangan tersebut, kegiatan pengabdian kepada masyarakat di tahun 2020 yang bertema: Penerapan Model Pengelolaan Sampah "Pojok Kangpisman” di Kecamatan Cinambo Kota Bandung dilaksanakan, khususnya di wilayah rukun warga yang telah berhasil menerapkan gerakan Kangpisman. Mengingat kegiatan pengabdian masyarakat dilaksanakan dalam masa pandemi covid-19, maka pelaksanaan pengelolaan sampah di Pojok Kangpisman lebih diarahkan pada pengelolaan sampah di tingkat rumah tangga. Oleh karena itu, kegiatan pengabdian masyarakat ini bertujuan untuk menerapkan model pengelolaan sampah Pojok Kangpisman di tingkat rumah tangga selama masa pandemi Covid-19, dengan melibatkan pengurus Kawasan Bebas Sampah (KBS) yang ada di tingkat Rukun Warga.

\section{METODE KEGIATAN}

\section{Kerangka Pemecahan Masalah}

Beradasarkan identifikasi permasalahan di lapangan, ditemukan bahwa belum adanya model pengelolaan sampah berbasis masyarakat di tingkat rukun warga yang mampu menggerakkan masyarakat untuk melakukan gerakan Kangpisman atas dasar kesadaran dan partisipasinya. Selain itu, stakeholder dan kelembagaan sosial yang ada di tingkat rukun warga belum dilibatkan secara maksimal dalam meluaskan gerakan Kangpisman terhadap semua rumah tangga. Oleh karena itu, kegiatan PPM tahun 2020 difokuskan pada kerangka pemecahan masalah sebagai berikut :

1. Menerapkan model pengelolaan sampah Pojok Kangpisman di tingkat 
rukun warga dengan melibatkan partisipasi aktif rumah tangga untuk melaksanakan gerakan Kangpisman atas dasar kesadaran dan partisipasinya serta melibatkan stakeholder yang ada di wilayah tersebut dalam proses implementasi model dan pendampingan. Indikator capaian kegiatan yaitu praktek rumah tangga dalam pengelolaan sampah melalui gerakan Kangpisman.

2. Melakukan review dan evaluasi terhadap penerapan model pengelolaan sampah Pojok Kangpisman melaui penyebaran angket terhadap rumah tangga yang ada di wilayah kajian. Indikator capaian kegiatan yaitu rumah tangga melakukan pemilah sampah organik dan anorganik dan volume sampah rumah tangga dikelola di Pojok Kangpisman.

\section{Realisasi Pemecahan Masalah}

Realisasi pemecahan masalah difokuskan pada upaya menerapkan model pengelolaan sampah Pojok Kangpisman di tingkat rukun warga, dengan cara:

1. Setiap rumah tangga harus mengolah sampah melalui gerakan Kangpisman dengan melibatkan stakeholder dan partisipasi masyarakat yang ada di lingkungannya.

2. Menentukan kebutuhan dan sasaran baru untuk perluasan gerakan Kangpsiman di wilayah lainnya.

\section{Khalayak Sasaran}

Sasaran dari kegiatan pengabdian pada masyarakat yaitu pengurus Kawasan Bebas Sampah (KBS) dan rumah tangga yang berada di wilayah RW 01 Kelurahan Sukamulya Kecamatan Cinambo Kota Bandung. Dari hasil pendataan, terdapat sebanyak 9 orang pengurus Kawasan Bebas Sampah (KBS) dan 51 rumah tangga yang bersedia untuk melakukan pengisian angket terkait dengan penerapan model pengelolaan sampah Pojok Kangpisman di wilayah tersebut.

\section{Tahapan Kegiatan}

Mengacu pada pemikiran Eric Kunto Aribowo (2018) tentang metode pelaksanaan pengabdian pada masyarakat, kegiatan dilaksanakan melalui beberapa tahap kegiatan, yaitu: (1) pembentukan tim; (2) perumusan tujuan; (3) identifikasi stakeholder; pengumpulan dan analisis kebutuhan; (5) penentuan prioritas solusi masalah; (6) persiapan; (7) implementasi; pendampingan; (9) review dan evaluasi; (10) menentukan kebutuhan dan sasaran baru.

Berdasarkan tahap kegiatan di atas, maka penerapan model pengelolaan sampah Pojok Kangpisman dilaksanakan sesuai dengan tahap tersebut, namun terdapat beberapa penyesuaian mengingat kegiatan ini dilaksanakan dalam kondisi pandemi Covid-19.

\section{HASIL DAN PEMBAHASAN}

\section{Gambaran Umum Rumah Tangga}

Dalam upaya untuk memeroleh informasi tentang rumah tangga yang menerapkan praktek pengelolaan sampah melalui gerakan Kangpisman, kegiatan pengabdian pada masyarakat menjaring informasi dari rumah tangga di wilayah kegiatan dengan menyebarkan angket. Angket ini disebarkan oleh pengurus Kawasan Bebas Sampah (KBS) di wilayah setempat setelah terlebih dahulu menyampaikan kegiatan sosialisasi dan edukasi tentang gerakan Kangpisman.

Terdapat sebanyak 51 rumah tangga yang bersedia melakukan pengisian angket secara online tentang praktek pengelolaan sampah melalui gerakan Kangpisman. Rumah tangga dipilih dengan kriteria: (1) salah satu anggota keluarga memiliki handphone yang dapat mengakses angket online dan mampu mengisi angket; (2) rumah tangga bertempat di wilayah kegiatan; (3) sudah memeroleh sosialisasi dan edukasi tentang gerakan Kangpisman.

Dari hasil angket diketahui bahwa rumah tangga umumnya adalah penduduk yang sudah menetap dalam waktu yang relatif lama yaitu lebih dari 10 tahun (82\%). Hal tersebut menunjukkan bahwa masyarakat yang mendiami wilayah tersebut adalah masyarakat 
yang telah beradaptasi dengan lingkungan sosialnya secara baik. Namun demikian, ada rumah tangga yang baru menetap di bawah 10 tahun (18\%). Lama menetap rumah tangga memberikan informasi bahwa masyarakat mengetahui setiap perubahan yang terjadi di wilayahnya. Hal ini menjadi salah satu pertimbangan bahwa upaya pengelolaan sampah berbasis masyarakat mudah untuk dikembangkan dalam lingkup masyarakat, karena ikatan sosial sudah terbangun dalam waktu yang cukup lama. Martinawati, dkk (2016) menyatakan bahwa usia dan lama bermukim mempunyai hubungan dengan tingkat partisipasi masyarakat terhadap pengelolaan sampah.

Dikaji dari status kepemilikan rumah, mayoritas rumah tangga memiliki rumah sendiri (86\%), dan hanya terdapat $14 \%$ rumah tangga yang menempati rumah sewa. Informasi ini menunjukkan bahwa keikutsertaan masyarakat dalam pengelolaan sampah merupakan gerakan kesadaran bersama untuk menjaga kebersihan lingkungan. Oleh karena itu, gerakan Kangpisman akan lebih mudah diterapkan khususnya pada rumah tangga yang memiliki status rumah sendiri.

Dikaji dari pekerjaan suami, mayoritas bekerja sebagai wiraswasta (41\%) dan karyawan/buruh (27\%). Jenis pekerjaan memberikan informasi tentang peluang pengelolaan sampah dikaji dari struktur pekerjaan masyarakat yang sebagian besar bekerja sebagai wiraswasta. Selanjutnya dikaji dari pekerjaan istri, mayoritas adalah sebagai ibu rumah tangga (74\%), dan hanya sebagian kecil yang bekerja sebagai karyawan swasta, pedagang, guru dan wiraswasta. Informasi tersebut menunjukkan bahwa istri yang tidak bekerja memberikan peluang pada adanya keterlibatan dalam proses pengelolaan sampah di tingkat rumah tangga. Waktu yang dimiliki ibu rumah tangga dapat dimanfaatkan untuk memperoleh nilai tambah dalam proses pengelolaan sampah dengan cara memanfaatkan kembali sampah menjadi barang yang bernilai ekonomi.

Masyarakat di wilayah kegiatan umumnya memiliki tingkat pendidikan yang cukup baik. Pendidikan suami umumnya adalah Sekolah Menengah Atas yaitu sebanyak 45\%, dikuti dengan tingkat pendidikan D4/S1 sebanyak 25\% dan S2 sebanyak 6\%. Begitupun dengan pendidikan istri umumnya berpendidikan Sekolah Menengah Atas sebesar 43\% diikuti dengan tingkat pendidikan D4/S1 sebanyak 25\%. Menurut Nugraha, et al., (2018), semakin baik persepsi masyarakat terhadap pengelolaan sampah rumah tangga, semakin tinggi tingkat partisipasi masyarakat dalam pengelolaan sampah rumah tangga. Sebaliknya semakin negatif persepsi seseorang terhadap pengelolaan sampah rumah tangga, akan semakin rendah partisipasinya dalam pengelolaan sampah rumah tangga. Hal ini menunjukkan bahwa tingkat pendidikan yang baik dapat membentuk persepsi yang baik, dan persepsi yang baik berkorelasi pada adanya partisipasi masyarakat dalam pengelolaan sampah. Selain itu, tingkat pendidikan yang cukup baik, merupakan faktor yang memengaruhi perilaku bersih.

Pendapat yang sama dikemukakan oleh Widyasari (2017) bahwa pendidikan sebagai salah satu faktor internal yang mempengaruhi partisipasi dalam kebersihan lingkungan. Begitupun Wichitra Singhirunnusorn, Kidanun Donlakorn dan Warapon Kaewhanin (2017) menyatakan bahwa atribut demografis dan faktor sosial ekonomi memainkan peran kecil dalam pemisahan sampah dan perilaku daur ulang di tingkat rumah tangga. Sementara itu, pengetahuan dan sikap lingkungan berkontribusi terhadap persepsi orang, kesadaran mereka, dan partisipasi mereka dalam proyek daur ulang berbasis masyarakat.

\section{Model Pengelolaan Sampah "Pojok Kangpisman"}

Kota Bandung saat ini gencar melakukan upaya penanganan sampah, diantaranya melalui Program Kawasan Bebas Sampah (KBS). Kawasan Bebas Sampah (KBS) adalah suatu kawasan dimana sistem pengelolaan sampahnya dijalankan secara mandiri oleh masyarakat. Sebuah kawasan disebut sebagai Kawasan Bebas Sampah (KBS) jika tidak ada sampah bertebaran di seluruh 
kawasan, baik di jalan, selokan/sungai, Tempat Penampungan Sementara (TPS), area pasar atau daerah komersil dan tempat lainnya (Humas Bandung, 2018). Dalam upaya untuk mewujudkan program Kawasan Bebas Sampah (KBS), sampah perlu dikelola agar sampah yang tadinya bertebaran di tempat tertentu dapat berkurang.

Tahapan yang yang harus dilakukan dalam mewujudkan Kawasan bebas Sampah yaitu : (1) melakukan pemilahan sampah organik dan anorganik; (2) mengolah sampah organik di kawasan dengan membuat lubang biopori atau dimanfaatkan untuk bahan pupuk kompos; (3) mengelola sampah anorganik bernilai jual dengan potensi yang ada di kawasan, diantaranya dengan membangun Bank Sampah; dan (4) membuang sampah residu ke TPS. Pelaksanaan progam Kawasan Bebas Sampah akan efektif apabila adanya keterlibatan aktif dan sinergitas seluruh masyarakat mulai dari tingkat individu, keluarga, Rukun Tetangga (RT), Rukun Warga (RW), kelurahan, petugas pengumpul sampah, PD Kebersihan, Pemerintah Kota Bandung dan pihak swasta. Melalui program Kawasan Bebas Sampah (KBS), maka tidak ada lagi sampah yang dibuang di sembarang tempat termasuk ke sungai (Humas Bandung, 2018).

Saat ini, Kota Bandung juga sedang menggalakan gerakan Kangpisman. Gerakan Kangpisman adalah gerakan kurangi, pisahkan dan manfaatkan sampah mulai dari sumbernya yaitu rumah tangga. Melalui kebiasaan memisahkan sampah, maka sampah akan terkurangi dan dimanfaatkan kembali tanpa harus dikirim ke TPA. Gerakan Kangpisman telah menerapkan gaya hidup nol sampah (zero waste) dan prinsip dasarnya adalah pengelolaan sampah yang bertanggung jawab. Dengan melakukan aktivitas kurangi, pisahkan dan manfaatkan sampah (Kangpisman) berarti telah turut bekerja sama dengan pemerintah untuk mewujudkan lingkungan yang bersih dan sehat, serta mengubah pandangan masyarakat terhadap sampah. Walaupun pada awalnya sampah dianggap sebagai masalah dan hanya menjadi tanggung jawab pemerintah, namun melalui gerakan Kangpisman, semua warga masyarakat diajak untuk bertanggung jawab dalam pengelolaan sampah seperti yang tertuang dalam UU no 18 tahun 2018 Pasal 12 bahwa "Setiap orang dalam pengelolaan sampah rumah tangga dan sampah sejenis sampah rumah tangga wajib mengurangi dan menangani sampah dengan cara yang berwawasan lingkungan”. Dengan demikian, mengelola sampah itu adalah kewajiban masyarakat untuk mewujudkan lingkungan yang bersih dan sehat. Mengurangi penggunaan barang sekali pakai, terutama yang dibuat dari bahan yang tidak bisa didaur ulang, akan mencegah terjadinya penumpukan sampah.

Dalam upaya untuk mendukung program Kota Bandung dalam pengelolaan sampah melalui gerakan Kangpisman, dibuat sebuah model pengelolaan sampah di tingkat Rukun Warga yang dinamakan "Pojok Kangpisman”. Pojok Kangpisman adalah wahana edukasi dan sosialisasi dalam pengolahan sampah yang ada di wilayah baik pengolahan sampah organik maupun anorganik. Prinsip kerja di Pojok Kangpisman adalah masyarakat berkolaborasi dalam melakukan pengolahan sampah, sehingga sampah yang ada di rumah tangga dapat dikurangi, dipisahkan dan dimanfaatkan agar lingkungan yang bersih dan sehat dapat diwujudkan.

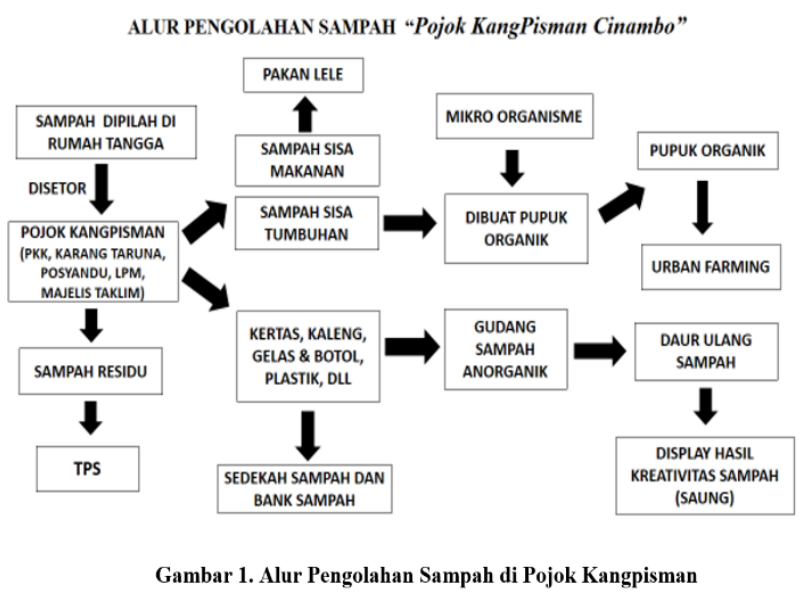

Alur pengelolaan sampah di Pojok Kangpisman terbagi atas dasar jenis sampahnya, yaitu sampah organik dan sampah anorganik. Untuk alur sampah organik, berupa sampah sisa tumbuhan dan sisa makanan, pengelolaannya dapat dilakukan melalui komposter dan bata terawang yang hasilnya 
dapat menjadi pupuk organik untuk urban farming atau dapat dijadikan pakan bagi ternak lele/ikan yang ada di Pojok Kangpisman. Sementara itu alur pengelolaan sampah anorganik berupa kertas, kaleng, gelas, botol plastik, dan lain-lain, setelah dilakukan pemilahan berdasarkan jenisnya di tingkat rumah tangga, dikumpulkan di gudang sampah anorganik atau kontainer untuk dijual atau didaur ulang menjadi barang yang bernilai ekonomi atau menjadi sedekah sampah bagi petugas sampah yang bekerja di Pojok Kangpisman. Untuk jenis sampah residu, apabila tidak dikelola di wilayah tersebut, dibuang ke TPS terdekat untuk selanjutnya diangkut oleh petugas dari PD. Kebersihan Kota Bandung.

Penerapan model pengelolaan sampah Pojok Kangpisman tersebut selain menuntut adanya partisipasi masyarakat dalam prosesnya, juga perlu melibatkan stakeholder dan dan kelembagaan sosial yang ada di tingkat Rukun Warga, agar gerakan Kangpisman tetap berjalan dan terjaga kesinambungannya.

\section{Tahapan Pelaksanaan Kegiatan}

Pelaksanaan penerapan model pengelolaan sampah "Pojok Kangpisman" dilaksanakan mengikuti pemikiran dari Eric Kunto Aribowo (2018) yang terdiri dari 10 tahapan. Berikut kegiatan untuk setiap tahapnya:

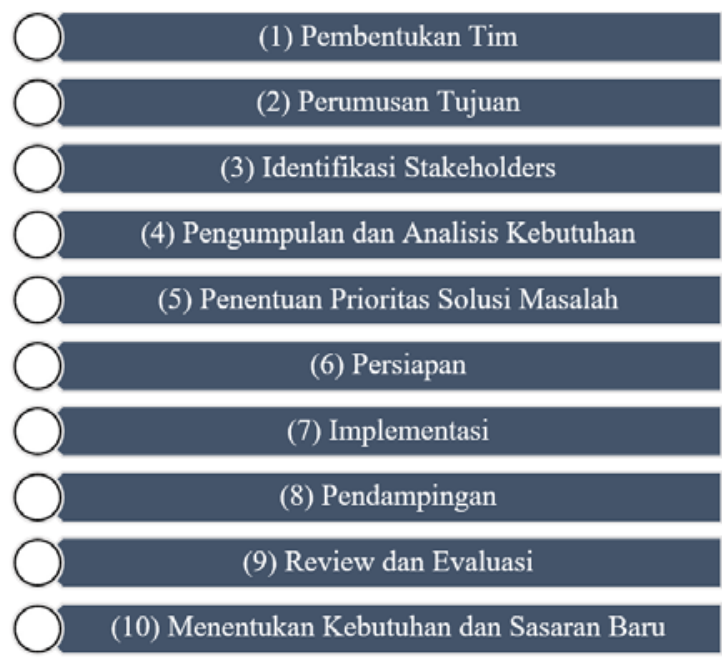

Bagan 1. Tahapan Pelaksanaan Kegiatan pada Masyarakat

\section{Tahap 1:}

Pelaksanaan kegiatan pengabdian pada masyarakat diawali dengan mengadakan pembentukan tim. Tim yang terbentuk untuk kegiatan ini adalah para pengurus Kawasan Bebas Sampah (KBS) di tingkat rukun warga yang sudah terlibat sejak awal kegiatan di tahun 2018 dalam kegiatan sosialisasi dan edukasi Kangpisman serta kegiatan uji coba model pengelolaan sampah melalui gerakan Kangpisman yang dilaksanakan pada tahun 2019. Keterlibatan pengurus KBS dalam setiap tahap kegiatan memberikan pengaruh terhadap perluasan gerakan Kangpisman di wilayah tersebut. Pembentukan tim dilakukan selain bertujuan untuk melibatkan partisipasi aktif dari para pengurus KBS dalam implementasi model, juga merupakan bagian dari kegiatan pemberdayaan masyarakat.

\section{Tahap 2:}

Perumusan tujuan dilakukan untuk mengarahkan kegiatan pada tahap realisasi pemecahan masalah. Tujuan dari kegiatan yaitu sampah rumah tangga di tingkat rukun warga baik sampah organik maupun anorganik diolah melalui gerakan Kangpisman dengan melibatkan stakeholder dan partisipasi masyarakat yang ada di lingkungannya serta menentukan kebutuhan dan sasaran baru untuk perluasan gerakan Kangpsiman di wilayah lainnya. Perumusan tujuan ini menjadi pedoman dalam pelaksanaan kegiatan masyarakat yang dilaksanakan di tahun 2020 .

\section{Tahap 3:}

Identifikasi stakeholder dilakukan agar kegiatan pengabdian pada masyarakat memperoleh dukungan dari stakeholder yang ada di wilayah tersebut, sehingga model pengelolaan sampah yang diterapkan mampu menggerakan masyarakat dalam pengelolaan sampah melalui gerakan Kangpisman. Stakeholder yang terlibat dalam kegiatan pengabdian pada masyarakat terdiri dari lurah, ketua RW dan ketua RT. Pelibatan stakeholder dalam kegiatan ini sangat penting, karena tanpa adanya dukungan dari stakeholder, maka pengelolaan sampah melalui gerakan Kangpisman tidak akan berhasil dengan baik. 


\section{Tahap 4:}

Pengumpulan dan analisis kebutuhan, dilakukan untuk memperoleh informasi dari masyarakat yang ada di wilayah kegiatan terkait dengan kebutuhan akan pemecahan masalah dalam pengelolaan sampah. Kegiatan ini dilakukan dengan cara mengumpulkan informasi baik dari masyarakat, pengurus KBS maupun stakeholder di wilayah kegiatan dengan melakukan focus group discussion (FGD) secara virtual. Adapun informasi yang terkumpul terkait dengan kebutuhan masyarakat dalam pengelolaan sampah meliputi:

a. Lahan pengolahan sampah Pojok Kangpisman

b. Fasilitas pengolahan sampah baik untuk sampah organik maupun anorganik

c. Pembentukkan kepengurusan dalam pengelolaan sampah

d. Pengaturan jadwal pengolahan sampah

e. Pelatihan tentang daur ulang sampah

f. Pendampingan dalam pembentukkan Bank Sampah

g. Fasilitas pengolahan sampah secara terpilah di tingkat rumah tangga

\section{Tahap 5:}

Penentuan prioritas solusi masalah, merupakan langkah yang sudah mengarahkan kegiatan pengabdian masyarakat pada prioritas yang menjadi kebutuhan utama dari masyarakat. Prioritas terhadap solusi masalah ditetapkan berdasarkan kemampuan yang dimiliki oleh tim periset, masyarakat dan stakeholder baik dari segi waktu, biaya dan tenaga serta potensi yang dimiliki terkait fasilitas pengolahan sampah yang ada di wilayah tersebut. Prioritas solusi masalah dititikberatkan pada pengolahan sampah di tingkat rumah tangga. Kegiatan ini penting, karena rumah tangga sebagai sumber penghasil sampah merupakan faktor yang menentukan keberhasilan kegiatan.

\section{Tahap 6:}

Persiapan diawali dengan melaksanakan kegiatan FGD dengan seluruh pengurus KBS yang ada di wilayah RW 01 Kelurahan Sukamulya Kecamatan Cinambo Kota Bandung. FGD dilaksanakan sebanyak dua kali dengan topik FGD ke-1 tentang pengelolaan sampah di tingkat rumah tangga dan topik FGD ke-2 tentang keterlibatan stakeholder dan kelembagaan masyarakat dalam melaksanakan Gerakan Kangpisman selama masa pandemi covid-19. Diskusi ini dilakukan untuk mendapat gambaran mengenai proses pengelolaan sampah yang dilaksanakan sebelum dan selama pandemi Covid-19.

\section{Tahap 7:}

Implementasi, merupakan tahap pelaksanaan penerapan model pengelolaan sampah Pojok Kangpisman di wilayah kegiatan dengan tujuan dan khalayak sasaran yang telah ditetapkan sebelumnya. Mengingat kondisi pandemi Covid-19, maka pada tahap implementasi, penerapan model Pojok Kangpisman dilaksanakan di tingkat rumah tangga dengan cara mensosialiasikan dan mengedukasi gerakan Kangpisman pada setiap rumah tangga yang ada di wilayah tersebut. Setiap rumah tangga harus melakukan pengolahan sampah sesuai dengan jenisnya dengan melakukan gerakan Kangpisman.

Tabel 1. Gerakan Kangpisman

\begin{tabular}{|c|c|c|}
\hline $\begin{array}{l}\text { KANG - Kurangi } \\
\text { Setiap hari kita harus } \\
\text { membiasakan : }\end{array}$ & $\begin{array}{c}\text { PIS - Pisahkan } \\
\text { Di rumah kita dapat membagi } \\
\text { tempat sampah : }\end{array}$ & $\begin{array}{c}\text { MAN - Manfaatkan } \\
\text { Sampah yang sudah dipisahkan, } \\
\text { dimanfaatkan sesuai jenisnya : }\end{array}$ \\
\hline $\begin{array}{l}\text { Mengurangi penggunaan } \\
\text { kantong plastik, } \\
\text { Styrofoam, dan bahan } \\
\text { lain yang sulit diurai oleh } \\
\text { alam }\end{array}$ & $\begin{array}{l}\text { Sampah jenis 1: } \\
\text { Sampah sisa makanan dan } \\
\text { tumbuhan ditempatkan pada } \\
\text { ember tertutup }\end{array}$ & $\begin{array}{l}\text { Sampah jenis I diolah ke dalam } \\
\text { biopori, komposter, takakura, bata } \\
\text { terawang, biodigester, maggot } \\
\text { BSF, serta menjadi makanan } \\
\text { termak dan kascing }\end{array}$ \\
\hline $\begin{array}{l}\text { Menggunakan kembali } \\
\text { barang-barang masih } \\
\text { bisa digunakan }\end{array}$ & $\begin{array}{l}\text { Sampah jenis 2: } \\
\text { Kertas, kaleng, gelas dan botol } \\
\text { plastik ditempatkan pada kotak } \\
\text { kardus }\end{array}$ & $\begin{array}{l}\text { Sampah jenis } 2 \text { dapat dijadikan } \\
\text { sedekah sampah atau diberikan } \\
\text { kepada bank sampah terdekat }\end{array}$ \\
\hline $\begin{array}{l}\text { Membawa kantong } \\
\text { belanja, tempat makan } \\
\text { dan minum sendiri ketika } \\
\text { bepergian }\end{array}$ & $\begin{array}{l}\text { Sampah jenis } 3 \text { : } \\
\text { Sampah lainnya ditempatkan pada } \\
\text { tong sampah }\end{array}$ & $\begin{array}{l}\text { Sampah jenis } 3 \text { dibawa ke Tempat } \\
\text { Penampungan Sementara (TPS) } \\
\text { untuk diangkut ke tempat } \\
\text { pemrosesan akhir oleh } \\
\text { PD. Kebersihan }\end{array}$ \\
\hline & & \\
\hline
\end{tabular}

Tahap 8:

Pendampingan dilakukan setelah model Pojok Kangpisman disosialisasikan dan diterapkan di tingkat rumah tangga. Pendampingan dilakukan oleh para pengurus Kawasan Bebas Sampah (KBS) kepada seluruh rumah tangga yang ada di wilayahnya. Keterlibatan pengurus KBS dalam kegiatan pendampingan sangat penting, karena kegiatan pemecahan masalah terkait dengan pengelolaan sampah menuntut adanya keterlibatan dan kolaborasi antara semua pihak, sehingga keberlanjutan kegiatan ini dapat tetap berlangsung sesuai dengan kebutuhan masyarakat. 


\section{Tahap 9:}

Review dan evaluasi, dilaksanakan dengan menyebarkan angket kepada rumah tangga yang ada di wilayah kegiatan. Penyebaran angket diperlukan untuk mendapat gambaran mengenai tanggapan masyarakat terhadap penerapan model Pojok Kangpisman serta hambatan yang dihadapi rumah tangga dalam pengelolaan sampah melalui gerakan Kangpisman.

Tahap 10:

Menentukan kebutuhan dan sasaran baru, merupakan tahap terakhir dari kegiatan pengabdian pada masyarakat. Tahap ini akan berlanjut apabila penerapan model pengelolaan sampah di tingkat rukun warga dianggap berhasil dan tahap berikutnya adalah menentukan kebutuhan dan sasaran baru dalam perluasan gerakan Kangpisman di wilayah lainnya. Tahap ini belum dapat dilakukan mengingat kondisi pandemi Covid-19 saat ini yang mengharuskan semua masyarakat mengikuti semua protokol kesehatan untuk menghindari terjadinya penyebaran virus korona.

\section{Penerapan Model Pengelolaan Sampah "Pojok Kangpisman"}

Pengelolaan sampah di wilayah kegiatan selama masa pandemi Covid-19 mengalami perubahan dengan sebelum terjadinya pandemi. Sampah anorganik yang seharusnya disetorkan oleh setiap rumah tangga ke Pojok Kangpisman, kini tidak bisa dilakukan mengingat harus menghindari adanya kerumunan dan menjaga protokol kesehatan. Saat ini, sampah dari rumah tangga yang telah dipilah kemudian akan dititipkan untuk sementara waktu di rumah pengurus KBS baik di tingkat RW/RT atau disetorkan langsung kepada petugas kebersihan.

Peran yang dilakukan oleh pengurus KBS baik di tingkat Rukun Warga (RW) maupun Rukun Tetangga (RT) selama masa pandemi yaitu tetap melakukan sosialisasi dan edukasi Kangpisman secara door to door kepada semua rumah tangga di wilayah tersebut. Selain itu, tetap melakukan pemantauan terhadap aktivitas pengelolaan sampah yang dilakukan oleh warga masyarakat. Tindakan ini dilakukan untuk mencegah dan menghindari penyebaran covid-19.

Upaya yang dilakukan oleh rumah tangga selama masa pandemi Covid-19, yaitu tetap melakukan pemilahan sampah. Sampah anorganik dititipkan kepada pengurus KBS atau dijual langsung kepada pengepul. Sementara itu, sampah organik dikelola oleh masingmasing rumah tangga dengan cara membuat komposter sederhana di rumahnya. Bagi rumah tangga yang tidak mengelola sampah organik, sampah langsung disetorkan ke petugas sampah. Hal ini menunjukkan bahwa pemberian intervensi efektif dapat meningkatkan pengetahuan dan praktik dalam pengelolaan sampah rumah tangga (Widiyanto, dkk, 2019).

Peran kelembagaan masyarakat seperti PKK dan Posyandu dalam pengelolaan sampah selama pandemi Covid-19, menunjukkan bahwa PKK tingkat kelurahan dan RW melakukan pemantauan terkait pengelolaan sampah yang telah dilakukan oleh masyarakat dengan cara terjun langsung ke lapangan bersama para tokoh masyarakat dan kelompok kerja untuk memonitor perkembangan yang terjadi di tingkat Rukun Tetangga dan Rukun Warga. Hasil pemantauan tersebut dapat menjadi pertimbangan dalam memperluas realisasi gerakan Kangpisman baik di lingkungan RW 01 Kelurahan Sukamulya maupun RW lainnya di wilayah kelurahan tersebut.

Pimpinan pemerintah setempat yaitu Lurah maupun ketua RW selalu memberikan dorongan agar kegiatan pengelolaan sampah melalui gerakan Kangpisman dapat terus dilaksanakan dengan baik di masyarakat. Namun, dukungan dana terhadap kegiatan tersebut selama masa pandemi Covid-19 belum ada, sehingga semua kegiatan yang telah dilakukan oleh masyarakat adalah murni dari masyarakat. Adapun bentuk dukungan yang diberikan oleh pemerintah yaitu menugaskan petugas kebersihan untuk mengumpulkan sampah rumah tangga setiap hari Senin dan Kamis setiap minggunya. Ismaila and Filson Maratur Sidjabata (2019) menyatakan bahwa 
salah satu upaya untuk memaksimalkan partisipasi masyarakat dalam kegiatan pengelolaan sampah adalah dengan melakukan sosialisasi tentang manfaat ekonomi dan manfaat persampahan dengan melakukan pengelolaan sampah. Partisipasi masyarakat yang tinggi ini dikarenakan masyarakat telah mendapatkan manfaat dari sampah

Rencana yang akan dilakukan terkait dengan pengelolaan sampah dan gerakan Kangpisman di Kelurahan Sukamulya, yaitu merealisasi Pojok Kangpisman di tempat lain yang lebih luas dan representatif. Di tempat yang direncanakan tersebut, tersedia tempat pemilahan sampah organik dan anorganik, gudang penyimpanan sampah anorganik, kolam lele, pojok literasi dan tempat edukasi untuk pemanfaatan sampah anorganik. Diharapkan pengelolaan sampah yang telah dan akan terus berkembang dapat menjadi inspirasi bagi masyarakat di wilayah lainnya. Kondisi ini memperlihatkan bahwa proses pengelolaan sampah Pojok Kangpisman telah semakin meningkatkan kesadaran masyarakat akan pentingnya pengelolaan sampah.

\section{Faktor Penghambat dalam Pengelolaan Sampah di Tingkat Rumah Tangga}

Dalam pelaksanaan pengelolaan sampah di tingkat rumah tangga, terdapat beberapa faktor penghambat baik faktor internal maupun eksternal. Terkait dengan upaya mengurangi penggunaan kantong plastik/styrofoam atau bahan lainnya yang sulit terurai oleh alam, rumah tangga telah melakukan upaya pengurangan penggunaan kantong plastik. Hal tersebut terlihat dari adanya upaya pemisahan dan penggunaan kembali kantong plastik yang sudah dipakai. Namun hambatan yang dihadapi oleh rumah tangga yaitu semua tempat pertokoan atau tempat perbelanjaan menyediakan plastik untuk barang belanjaannya. Meskipun sudah ada upaya rumah tangga mengurangi penggunaan kantong plastik, namun plastik masih digunakan untuk berbagai keperluan. Pemerintahan kota dan kabupaten telah melakukan pelarangan terhadap penggunaan plastik, namun menjadi kurang efektif karena tidak ada larangan yang tegas untuk penggunaannya. Disisi lain, masih lemahnya larangan tersebut, maka semua tempat perbelanjaan masih menggunakan kantong plastik. Hal ini berpengaruh pada sulitnya mengubah kebiasaan masyarakat untuk mengurangi kantong plastik.

Terkait dengan menggunakan kembali sampah anorganik, hambatannya adalah kurang waktu yang dimiliki oleh rumah tangga untuk memanfaatkan kembali sampah yang sudah tidak digunakan lagi. Hambatan lainnya adalah kurangnya lahan dan ruang yang tersedia di rumah untuk menyimpan barang-barang hasil daur ulang sampah. Oleh karena itu, adanya gudang penyimpanan daur ulang sampah di Pojok Kangpisman sangat membantu rumah tangga untuk menyimpan hasil kreasinya dari sampah anorganik.

Dalam program Kangpisman, masyarakat diharapkan mengubah perilaku untuk selalu mengurangi sampah dengan cara membawa kantong belanja dan tempat makan dan minum sendiri. Hambatan yang sering dihadapi masyarakat yaitu sering lupa membawa, merasa ribet dan belum terbiasa untuk membawa kantong belanja sendiri. Namun dengan adanya sosialisasi dan edukasi yang efektif tentang gerakan Kangpisman, maka secara perlahan-lahan dapat mengubah perilaku masyarakat untuk selalu membawa kantong belanja sendiri.

Selanjutnya, dalam upaya untuk mengurangi sampah yang diproduksi, masyarakat didorong untuk mengurangi konsumsi makan dan minum dan menghabiskannya. Masyarakat tidak mengalami kesulitan untuk melakukan hal tersebut. Apabila terdapat sisa makanan, itu merupakan sisa makanan yang tidak disukai atau disisakan karena sudah merasa kenyang. Sementara itu dalam upaya untuk memisahkan sampah sisa makanan dan tumbuhan, hambatan yang ditemukan adalah selain menambah pekerjaan, juga karena rumah tangga tidak memiliki tempat sampah terpilah khusus untuk sisa makanan dan tumbuhan. Beberapa rumah tangga masih menganggap memisahkan sampah pada wadah yang terpisah dianggap 
ribet. Kondisi yang sama juga terjadi ketika memisahkan kertas, kaleng, gelas dan botol plastik dan sampah residu. Hambatannya adalah kurangnya fasilitas yang memadai untuk memisahkan sampah dalam wadah secara terpisah. Selain itu, tidak semua anggota dalam keluarga berperilaku sama untuk memilah sampah sesuai dengan jenisnya.

Dalam mengolah sampah organik dengan menggunakan komposter atau bata terawang, masyarakat umumnya sudah mengetahui cara mengolahnya. Namun di masa pandemi Covid-19, masyarakat diharuskan mengolah sampah organik secara mandiri di rumahnya. Hal ini menjadi kendala bagi masyarakat, karena terbatasnya tempat sampah yang dimiliki dan pengolahan sampah organik membutuhkan waktu yang lama. Sementara itu, penyetoran sampah anorganik ke Bank Sampah, selama masa pandemi Covid-19 tidak dilakukan. Selain menghindari adanya kerumunan di satu tempat juga karena lokasi Bank Sampah yang cukup jauh dari lokasi tempat tinggal. Namun sampah dari rumah tangga umumnya diambil oleh petugas kebersihan dengan jadwal yang sudah ditentukan yaitu setiap hari senin dan kamis setiap minggunya.

Hasil kajian Katya Stoeva dan Stina Alriksson (2017) menyatakan bahwa kurangnya kondisi yang tepat untuk pemisahan limbah dapat mencegah individu dari berpartisipasi dalam proses ini, terlepas dari sikap positif mereka. Ketika masyarakat puas dengan kondisi setempat untuk pemisahan limbah, perilaku mereka justru bergantung pada sikap pribadi mereka terhadap pemisahan dan daur ulang limbah. Selanjutnya Lishan Xiao, et.al. (2017) mengidentifikasi faktor-faktor kunci yang memengaruhi kemauan lingkungan warga untuk berpartisipasi dalam pengelolaan limbah, dan menunjukkan bahwa faktor yang paling berpengaruh adalah pengetahuan warga, diikuti oleh motivasi sosial, sementara faktor kelembagaan memiliki efek positif terkecil. Warga yang memiliki informasi lebih baik dan tinggal di komunitas/ keluarga dengan perilaku yang lebih ramah lingkungan memiliki kecenderungan yang lebih besar untuk berpartisipasi dalam pengelolaan limbah berkelanjutan. Hal ini menunjukkan bahwa walapun masyarakat memiliki motivasi dan sikap postif terhadap pengelolaan sampah, namun harus disertai dengan fasilitas pengelolaan sampah yang memadai, agar masyarakat dapat berpartisipasi dalam prosesnya.

\section{Keberhasilan Gerakan Kangpisman}

Gerakan sosial adalah sebuah upaya perubahan yang diselenggarakan oleh sekelompok besar orang untuk mencapai tujuan tertentu yang diinginkan, umumnya perubahan sosial atau politik (Scott dan Marshall, 2009; Webster Dictionary, 2020). Gerakan sosial merupakan jenis aksi kelompok dan dapat melibatkan individu, organisasi atau bahkan keduanya. Terkait dengan gerakan Kangpisman dalam pengelolaan sampah, gerakan ini diinisiasi oleh pemerintah untuk melakukan perubahan di masyarakat terkait dengan pengelolaan sampah. Shannon (2011) mengemukakan bahwa gerakan sosial digambarkan sebagai struktur dan stategi organisasi yang dapat memberdayakan populasi masyarakat untuk meningkatkan tantangan yang efektif. Oleh karena itu, gerakan sosial memiliki siklus hidup. Sebuah gerakan sosial diciptakan, tumbuh dan mencapai keberhasilan atau gagal dan pada akhirnya gerakan sosial menyatu dan menjadi suatu siklus dalam kehidupan.

Gerakan Kangpisman yang diprakarsai pemerintah Kota Bandung, berangkat dari fakta bahwa permasalahan sampah akan menjadi bencana apabila tidak dilakukan perubahan paradigma pengelolaan sampah. Oleh karena itu, gerakan sosial Kangpisman dilakukan untuk menciptakan paradigma baru dalam masyarakat yang lebih peduli pada lingkungan khususnya sampah. Keberhasilan gerakan sosial pengelolaan sampah sangat bergantung pada banyak faktor seperti perencanaan pembangunan yang diarahkan pada terciptanya pembangunan yang berwawasan lingkungan, kesiapan infrastruktur pengelolaan sampah yang terpadu, dan masyarakat yang dipersiapkan untuk menerima terjadinya 
perubahan paradigma dalam pengelolaan sampah di tingkat rumah tangga. Jika semua itu dapat dilakukan secara simultan dan saling sinergi, maka perubaan perilaku masyarakat dalam pengelolaan sampah merupakan suatu keniscayaan yang sangat mungkin untuk dicapai. Mendorong perubahan perilaku pada masyarakat tanpa didukung oleh perubahan instrumen pendukung kehidupan yang lebih peduli pada kebersihan lingkungan, seperti kebijakan penggunaan plastik, budaya pengelolaan sampah, serta dukungan swasta akan sangat sulit untuk mencapai perubahan yang diinginkan jika tanpa dukungan dari semua pihak. Jing Ma, Keith W. Hipel (2016) menyatakan bahwa keberhasilan pengelolaan persampahan perkotaan sangat bergantung pada partisipasi semua pemangku kepentingan.

\section{SIMPULAN}

Kegiatan pengabdian pada masyarakat yang telah dilaksanakan selama tiga tahun telah berhasil menerapkan model alternatif pengelolaan sampah berbasis masyarakat, dengan mengadopsi gerakan Kangpisman dalam skala komunitas yang kecil di tingkat Rukun Warga (RW). Model tersebut telah menjadikan aktivitas pengelolaan sampah yang dilakukan oleh masyarakat lebih efektif, karena berada dalam lingkup yang lebih kecil dan masyarakat turut terlibat dalam prosesnya. Dasar dari adanya partisipasi masyarakat dalam pengelolaan sampah yaitu masyarakat adalah penduduk setempat yang sudah lama menetap di wilayah tersebut, memiliki rumah sendiri, pendidikannya cukup baik dan istri yang tidak bekerja menjadi potensi bagi adanya partisipasi dalam pengelolaan sampah. Namun, model pengelolaan sampah Pojok Kangpisman melalui gerakan Kangpisman akan berhasil dan efektif selain ditentukan oleh adanya keterlibatan stakeholder dalam proses pengelolaan sampah, juga ditentukan oleh adanya dukungan dari pemerintah terhadap pengadaan fasilitas yang memadai untuk pengelolaan sampah di tingkat rumah tangga.

\section{UCAPAN TERIMA KASIH}

Kegiatan Pengabdian kepada Masyarakat ini didukung oleh Universitas Padjadjaran melalui Hibah Internal Universitas Padjadjaran tahun 2020. Kami berterima kasih kepada semua pihak yang telah membantu dalam kegiatan ini.

\section{DAFTAR PUSTAKA}

Ariwibowo, Eric Kunto. 2018. Metode Pengabdian pada Masyarakat. (https://figshare.com/articles/figure/Me tode_Pelaksanaan_Pengabdian_kepada _Masyarakat/7011266/1, diakses Nopember 2020)

Berberoglu, Berch (ed). 2019. The Palgrave Handbook of Social Movements, Revolution, and Social Transformation. Palgrave Macmillan.

Biro Pusat Statistik. 2018. Laporan Indeks Perilaku Ketidakpedulian Lingkungan Hidup Indonesia. Jakarta.

Deric., Shannon. 2011. Political Sociology: Oppression, Resistance, and The State. Pine Forge Press. p. 150. ISBN 9781412980401.

Effendi, I. 2007. Meningkatkan Partisipasi Dalam Pembangunan Melalui Program Pemberdayaan (Orasi Ilmiah Sebagai Guru Besar Ilmu Penyuluhan). Universitas Lampung, Bandar Lampung

Ife, Jim dan Frank Tesoreiro. 2008. Community Development Alternatif Pengembangan Masyarakat di Era Globalisasi. Yogyakarta: Pustaka Belajar.

Humas Bandung. 2018. Delapan Kelurahan Jadi Role Model Kawasan Bebas Sampah. (https://www.kangpisman.com/delapan -kelurahan-jadi-role-model-kawasanbebas-sampah/, diakses Nopember 2020)

Humas Bandung. 2019. Kang Pisman pun Mendunia.

(https://humas.bandung.go.id/berita/kan g-pisman-pun-mendunia, diakses Nopember 2020) 
Ismaila, Yunita and Filson Maratur Sidjabata. 2019. Community Empowerment in Household Waste Management. Journal of Community Engagement (Jce). Volume 01, Number 01, September 2019, Page 24-29.

Istiningdias, D. S., Azijah, D. N., \& Argenti, G. (2019). PENINGKATAN PERAN AKTIF APARATUR DESA DAN PARTISIPASI MASYARAKAT DALAM UPAYA PELESTARIAN LINGKUNGAN MELALUI PELATIHAN PEMBUATAN ECOBRICKS. Kumawula: Jurnal Pengabdian Kepada Masyarakat, 2(2).

Jing Ma, Keith W. Hipel. 2016. Exploring Social Dimensions of Municipal Solid Waste Management Around The Globe - A Systematic Literature Review. Waste management. xxx (2016) $\mathrm{xxx}-$ $\mathrm{xxx}$.

Katya Stoeva, Stina Alriksson. 2017. Influence of Recycling Programmes on Waste Separation Behaviour. Waste Management. 68 (2017) 732-741.

Kementerian Lingkungan Hidup RI. 2020. KLHK: Indonesia Memasukoi Era Baru Pengelolaan Sampah. (http://ppid.menlhk.go.id/siaran_pers/br owse/2329, diakses 21 Februari 2020).

Kementerian Lingkungan Hidup RI. 2019. KLHK: 72 Persen Masyarakat Tak Peduli dengan Sampah Plastik. (https://www.cnnindonesia.com/teknol ogi/20190821164641-199423470/klhk-72-persen-masyarakattak-peduli-dengan-sampah-plastik, diakses 21 Agustus 2019).

Lishan Xiao, Guoqin Zhang, Yan Zhu, Tao Lin. 2017. Promoting Public Participation in Household Waste Management: Survey Based Method And Case Study In Xiamen City, China. Journal of Cleaner Production. 144 (2017), $313 e 322$.

Martinawati, Imron Zahri, M. Faisal. 2016. Partisipasi Masyarakat dalam Pengelolaan Sampah Rumah Tangga.
Jurnal Penelitian Sains. Vol 18, No 1, Januari 2016.

Ndraha, Talizuduhu. 1987. Pembangunan Masyarakat: Mempersiapkan Masyarakat Tinggal Landas. Jakarta: Bina Aksara.

Nugraha, Aditya, dkk. 2018. Persepsi dan Partisipasi Masyarakat terhadap Pengelolaan Sampah Rumah Tangga melalui Bank Sampah. Jurnal Pengelolaan Sumber Daya Alam dan Lingkungan. Vol 8, No 1, April 2018.

Scott, John; Marshall, Gordon. 2009. Social movements. A Dictionary of Sociology, Oxford : University Press.

Sekarningrum, B., Sugandi, Y. S., \& Yunita, D. (2020). SOSIALISASI DAN EDUKASI KANGPISMAN (KURANGI, PISAHKAN DAN MANFAATKAN SAMPAH). Kumawula: Jurnal Pengabdian Kepada Masyarakat, 3(1).

Singhirunnusorn, Wichitra, Kidanun Donlakorn, Warapon Kaewhanin. 2017. Household Recycling Behaviours And Attitudes Toward Waste Bank Project: Mahasarakham Municipality. Journal of ASIAN Behavioural Studies. Vol 2 (5) : 35-47

Undang-Undang Nomor 18 Tahun 2018 tentang Pengelolaan Sampah.

Wahyono, Sri. 2018. Konsep Pengelolaan Sampah Kota dan Kaji Terap Teknologi Penerapannya. Prosiding Seminar Nasional dan Konsultasi Teknologi Lingkungan. Jakarta, 20 September 2018.

Widiyanto, Agnes Fitria, Suratman, Nisrina Alifah, Tri Murniati, Oktafiani Catur Pratiwi. 2019. Knowledge and Practice in Household Waste Management. Kesmas: National Public Health Journal. Vol 13 (3), 112 - 116. 